\title{
Jaguar Persecution Without "Cowflict": Insights From Protected Territories in the Bolivian Amazon
}

\author{
Jillian Knox ${ }^{1}$, Nuno Negrões ${ }^{2,3}$, Silvio Marchini ${ }^{4}$, Kathrin Barboza ${ }^{2}$, Gladys Guanacoma ${ }^{2}$, \\ Patricia Balhau ${ }^{2,3}$, Mathias W. Tobler ${ }^{1}$ and Jenny A. Glikman ${ }^{1 *}$ \\ ${ }^{1}$ Institute for Conservation Research, San Diego Zoo Global, San Diego, CA, United States, ${ }^{2}$ ACEAA-Conservación \\ Amazónica, La Paz, Bolivia, ${ }^{3}$ Department of Biology \& CESAM, University of Aveiro, Aveiro, Portugal, ${ }^{4}$ Wildlife Conservation \\ Research Unit, University of Oxford, Oxford, United Kingdom
}

OPEN ACCESS

Edited by:

Tasos Hovardas,

University of Cyprus, Cyprus

Reviewed by:

Krzysztof Schmidt

Mammal Research Institute

(PAN), Poland

Amit Ronit,

University of Costa Rica, Costa Rica

*Correspondence:

Jenny A. Glikman

jaopy@hotmail.com

Specialty section:

This article was submitted to

Conservation,

a section of the journal

Frontiers in Ecology and Evolution

Received: 29 August 2019 Accepted: 03 December 2019 Published: 19 December 2019

Citation:

Knox J, Negrões N, Marchini S, Barboza K, Guanacoma G, Balhau P, Tobler MW and Glikman JA (2019)

Jaguar Persecution Without

"Cowflict": Insights From Protected Territories in the Bolivian Amazon.

Front. Ecol. Evol. 7:494.

doi: 10.3389/fevo.2019.00494
Persecution by humans is one of the most pressing threats to jaguars (Panthera onca) throughout the Americas, yet few studies have examined the killing of jaguars outside cattle-ranching communities. Although over one-third of the jaguar's range is formally protected, relatively little is known about human-jaguar relationships within protected areas and indigenous territories. Protected land within the Bolivian Amazon, considered a stronghold for the jaguar, contains communities who differ economically, legally, and socially from previously-studied human populations living with jaguars. Using in-person structured interviews, we investigated attitudes and norms related to jaguars and jaguar killing, self-reported past killing of jaguars, and demographic variables in two protected areas and an indigenous territory: Integrated Management Area (IMA) of Santa Rosa del Abuná (Santa Rosa, $n=224)$, Indigenous Territory Tacana II $(n=137)$, and Manuripi National Amazon Wildlife Reserve (MNAWR, $n=169$ ). Overall, people disliked (48.9\%) or felt neutral (26.8\%) toward jaguars. A relatively large number of people reported either being attacked or knowing someone who had been attacked by a jaguar: $15.45 \%$ in Santa Rosa, $14.20 \%$ in MNAWR, and $30.88 \%$ in Tacana II. Many respondents stated to have killed a jaguar, although the proportion differed among study areas: $20.39 \%$ of Santa Rosa, $55.47 \%$ of Tacana II, and $32.72 \%$ of MNAWR. People perceived jaguar persecution as relatively common: $44.9 \%$ of Santa Rosa, $90.8 \%$ of Tacana II, and $65.8 \%$ of MNAWR said their neighbors kill jaguars (i.e., descriptive norm). Also, 75.4\% of Santa Rosa, $89.1 \%$ of Tacana II, and $69.1 \%$ of MNAWR said that some of their family members and neighbors thought jaguar killing was good (i.e., subjective norm). Descriptive and subjective norms positively influenced both attitudes toward killing and past killing of jaguars. This perception of jaguar killing being common and socially-accepted, combined with high rates of past killing and a growing illegal trade of jaguar parts, may create an atmosphere conducive to widespread jaguar persecution in the Bolivian Amazon. We recommend management strategies that focus on preventing jaguar depredation of small domestic animals, lessening the perception of carnivore encounters as dangerous to decrease safety-related fears, and making large carnivore killing socially unacceptable (e.g., through social marketing).

Keywords: jaguars, large carnivores, human dimensions, coexistence, protected areas, Bolivia, Amazon, conservation psychology 


\section{INTRODUCTION}

Habitat loss and persecution by humans are the principal causes of the rapid declines in large carnivore populations worldwide (Ripple et al., 2014), whose long-term persistence is increasingly dependent on their survival in landscapes shared with people (Carter and Linnell, 2016; Glikman et al., 2019). Conflicts surrounding conservation are increasing in many areas, and large carnivores are particularly vulnerable, often because of livestock depredation and sometimes because of attacks on people (Inskip and Zimmermann, 2009). As top predators play a crucial role in maintaining biodiversity, population decreases due to humans can have extensive effects on ecosystems (Terborgh et al., 2002; Treves and Karanth, 2003; Garcia-Alaniz et al., 2010).

The jaguars' range has declined by more than half since 1900 (Sanderson et al., 2002; Zeller, 2007; de la Torre et al., 2017; Jędrzejewski et al., 2018). Within the remaining range, killing by humans is one of the most pressing threats to the species (Sanderson et al., 2002; Zeller, 2007; Galetti et al., 2013; Romero-Muñoz et al., 2019a). As human populations continue to grow and expand into the felid's habitat, understanding human-jaguar relationships is essential for developing successful conservation strategies (Manfredo and Dayer, 2004; Loveridge et al., 2010). Most studies on human-jaguar relationships have been carried out in cattle ranching areas, originally on large properties in the Pantanal of Brazil (Zimmermann et al., 2005; Azevedo and Murray, 2007) and the Llanos of Venezuela (Hoogesteijn and Chapman, 1997; Polisar et al., 2003) and later in smaller properties elsewhere (Foster et al., 2010; Rosas-Rosas and Valdez, 2010; Mexico: Figel et al., 2011; Costa Rica: Amit et al., 2013; Guatemala: Soto-Shoender and Main, 2013; Belize: Steinberg, 2016; Venezuela: Jẹdrzejewski et al., 2017). In contrast, relatively little is known about human-jaguar relationships and, in particular, jaguar persecution in forested land within and around protected areas, and in indigenous territories relying primarily on natural resources [with the exception of Carvalho (2019)'s examination of jaguar hunting in extractive reserves in the Brazilian Amazon]. This knowledge gap is significant, considering around one third (38\%) of the large felid's global distribution overlaps protected areas and most of the remaining range is in the Amazon basin (de la Torre et al., 2017). As development in the Amazon intensifies, understanding the communities that live with jaguars within these protected territories will be critical for successful protection.

The southwestern Amazon is a stronghold for the jaguar, containing some of the highest documented densities of the species (Tobler et al., 2013; Jędrzejewski et al., 2018). Bolivia is a hotspot for jaguars (U. S. Fish and Wildlife Service, 2018; Romero-Muñoz et al., 2019a), containing high priority populations and habitats (Sanderson et al., 2002). The issue of jaguar killing is particularly important in Bolivia, as increased trafficking of jaguar parts has been detected in the country in the last few years, adding an economic incentive for persecution. Between 2014 and 2016, 344 jaguar teeth were seized by Bolivian authorities, representing at least 87 individuals (Nuñez and Aliaga-Rossel, 2017). According to researchers, this rise in trafficking could be caused by the demand for feline parts in Chinese Traditional Medicine (Still, 2003; Fraser, 2018). Although the trade of jaguar parts is illegal in Bolivia, laws are rarely enforced. Intensified conflict and opportunistic domestic hunting also threaten the predator's survival (Castaño-Uribe et al., 2016). Despite significant efforts, relatively little is known about the drivers of jaguar persecution in Bolivia (Conforti and De Azevedo, 2003; Zimmermann et al., 2005; Palmeira et al., 2008; Porfirio et al., 2014).

Indigenous communities living within protected areas of the Bolivian Amazon differ economically, legally, and socially from previously-studied populations living with jaguars. These differences are significant to conservation strategies. For example, the well-documented threat of livestock depredation by jaguars (Crawshaw, 2004; Zimmermann et al., 2005; Cavalcanti et al., 2010; Marchini and Macdonald, 2012; Amit and Jacobson, 2017) might be less relevant to their persecution in Amazonian communities where livestock is not the main economic activity (Negrões et al., 2017). In support of this, Porfirio et al. (2014) found that fishers along the Pantanal perceived jaguar differently than ranchers in the same region. Nearly half (43.3\%) of the Bolivian Amazon is within an indigenous territory or a protected area, both of which legally limit deforestation (Tejada et al., 2016; Romero-Muñoz et al., 2019b). This study focuses on communities living in three areas in and around the northwestern region of the Bolivian Amazon, comprised of socioecological systems in which communities rely on forest resources for their livelihoods, and classified as protected territories.

Many factors influence human-carnivore interactions. For example, perceptions of and behavior toward wildlife can differ with demographic and socioeconomic status, including age, gender, and place of residence (Kellert et al., 1996) and with cultural group (Liu et al., 2011; Harvey et al., 2017). Experiences can also affect human-wildlife relationships. In particular, Marchini and Macdonald (2012) found that experiences with jaguars, such as depredation or attacks on humans, predicted intention to kill the species in ranching communities in Brazil. In addition, Carvalho (2019) linked jaguar hunting to education level, risk perceptions regarding the sanctions on such hunting, and the perception of the large carnivore as a threat to human safety.

One theoretical framework used to study human thought and behavior toward wildlife is the cognitive hierarchy (Fulton et al., 1996), which posits that cognitions (e.g., attitudes, beliefs, and norms) drive human behavior (Vaske and Donnelly, 1999; Jacobs et al., 2012). Attitudes are defined as positive or negative evaluations of objects or actions and have cognitive and affective components (Eagly and Chaiken, 1993; Verplanken et al., 1998; Ajzen, 2001). The affective component includes feelings, moods, and emotions about an object or behavior (Eagly and Chaiken, 1993). In this study, we examine the affective component of two attitude objects: jaguars and jaguar killing. Beliefs, the cognitive component, are "associations or linkages that people establish between the attitude object and various attributes" (Eagly and Chaiken, 1993). Beliefs about wildlife are based on attributes associated with the species (Carter et al., 2012). For example, people who believe that jaguars kill more people than dogs do each year may be more likely to perceive interactions 
with the large carnivore as negative. Using in-person structured interviews, we examined beliefs about jaguar attacks on humans, the risk of such attacks, and jaguar population size.

Norms are individual or shared standards that guide actions. Descriptive norms indicate an individual's perception of whether other people in the community perform a specific action (Cialdini et al., 1990; White et al., 2009). For example, an individual's beliefs about how many of his or her neighbors kill jaguars is a descriptive norm about jaguar killing. Normative beliefs are personal judgments about what is appropriate in different situations, for example, beliefs about whether jaguar populations should disappear in the next 5 years. Subjective norms reflect an individual's perception of whether others would approve of an action (Vaske and Whittaker, 2004; Marchini and Macdonald, 2012), for example, perceptions of whether family members and neighbors view that killing jaguars as acceptable or good.

In addition to the cognitive hierarchy framework, it is important to consider the role of emotions in human behavior toward wildlife. Emotions are a basic mental capacity and can shape mental processes and influence mental dispositions like memories, motivations, and decisions. Once activated, emotions often control human behavior (Manfredo, 2008; Jacobs et al., 2012; Jacobs and Vaske, 2019). Fear of large carnivores (Johansson et al., 2012; Sponarski et al., 2015), including jaguars (Engel et al., 2016; Amit and Jacobson, 2017), has been explored extensively. In this study, we explore demographic and socioeconomic variables, experiences with jaguars, and concepts from the cognitive hierarchy framework (e.g., attitudes and norms) and emotions regarding jaguars and the killing of jaguars, using in-person interviews. We interpret these results in the context of the distinct historical and social characteristics of each community. We compare our findings with human-jaguar relationships in other contexts, such as cattle-ranching areas, and then more broadly with the human dimensions of large carnivores conservation worldwide.

\section{MATERIALS AND METHODS}

\section{Study Areas}

This study focuses on communities living in three areas in and around the northwestern region of the Bolivian Amazon (Figure 1): the Integrated Management Area (IMA) of Santa Rosa del Abuná, the Indigenous Territory Tacana II, and the Manuripi National Amazon Wildlife Reserve. All three territories are legally protected and contain communities relying on natural resources for their livelihoods. In Bolivia's Northwestern Amazon, the economy centers on Brazil nut (Bertholletia excelsa) collection. The use, production, and export of Brazil nut employ about 7,000 people from local communities (excluding migratory workers $)^{1}$ Most Brazil nut harvest occurs deep in the forest, with collectors often working in close proximity to wildlife. For further subsistence, people collect non-timber forest products (e.g., Acaí), hunt, fish, raise some domestic animals (primarily

\footnotetext{
${ }^{1}$ http://www.amazonconservation.org/pdf/2017\%20Annual\%20Report\%20Final web.pdf
}

chickens, ducks, and pigs), and practice subsistence farming. Gold mining and forestry are also present in the areas. All three areas were chosen as study locations because they represent protected territories with different legal contexts, and they face increasing threats to their wildlife populations due to the development (e.g., roads, gas, and oil exploration).

\section{Santa Rosa del Abúna}

The IMA of Santa Rosa del Abúna (Santa Rosa) was established in April 2017 to promote sustainable development that does not conflict with biodiversity conservation. The area links the initiative of 20 communities to maintain a healthy forest under Bolivia's national forest policies ${ }^{2}$. Heralded as one of the most significant protected areas that Bolivia has created over the last decade, Santa Rosa is comprised of over 170,000 hectares (ha) of primary Amazonian rainforest. It lies in northern Bolivia, close to the Brazilian borders. The International Union for the Conservation of Nature (IUCN) classifies Santa Rosa as Category VI protected area, meaning that the sustainable use of natural resources is permitted ${ }^{3}$. The 2,200 people living in the IMA of Santa Rosa rely mainly on revenue generated by Brazil nut collection ${ }^{2}$. The communities that live inside this area include people of both Amazonian and Andean origins, who recently migrated to the region. Although the main economic activity is Brazil nut collection, income is supplemented with Acaí collection, small agricultural activities, agroforestry, and small domestic animals.

\section{Tacana II}

Tacana II is an indigenous territory located in the Madre de Dios river region of northern Bolivia, within the Ixiamas de la Abel Iturralde province. The territory, which covers about 350,000 ha, is home to more than 700 Tacana people. The population is distributed into four communities: Puerto Pérez, Las Mercedes, Toromonas, and El Tigre. Tacana II was created during the economic boom of Brazil nut extraction. The Tacana people have rights of tenure over their territory, granted by the Bolivian state. Their internal regulation of land management and natural resources is credited with preventing overexploitation of the Bolivian Amazon while promoting sustainable livelihoods ${ }^{3}$. Communities rely on Brazil nut collection as their primary source of income, although their livelihoods are supplemented with small agriculture, breeding of small domestic animals, forestry activities, and some gold mining.

\section{Manuripi National Amazon Wildlife Reserve}

The Manuripi National Amazon Wildlife Reserve (MNAWR) is a nationally-protected area located in the southwest region of the Department of Pando in northwestern Bolivia. Created in 1973, MNAWR, which spans over 725,000 ha, is the only nationallyprotected area in Bolivia containing Amazonian Humid Forests. It is also the only protected area representative of that ecosystem with an abundance of Brazil nut trees. Its current boundaries and denomination were defined by Supreme Decree No. 25906 in September 2000, placing the reserve under the administration

\footnotetext{
${ }^{2}$ https://www.andesamazonfund.org/blog/santarosa

${ }^{3}$ https://www.iucn.org/es/node/17721
} 


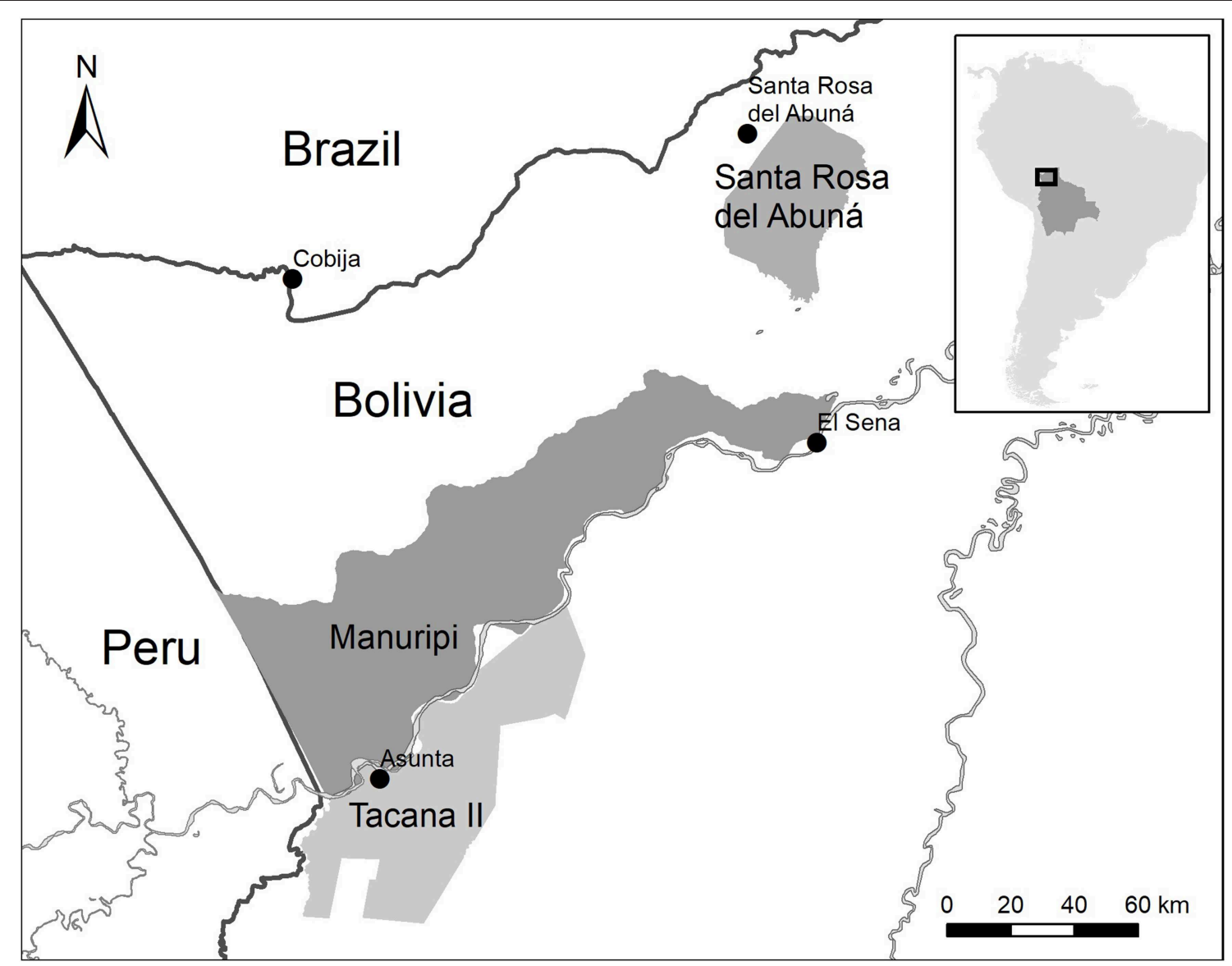

FIGURE 1 | Map of the study areas in Bolivia: Santa Rosa del Abuná (Santa Rosa), Tacana II, and Manuripi National Amazon Wildlife Reserve (MNAWR).

of the National Service for Protected Areas (SERNAP). MNAWR is the best-conserved area of the Madre de Dios, Acre, and Pando (MAP) region of Amazonian Forests containing Brazil nut ${ }^{4}$ About 1,500 people live within the wildlife reserve, within 9 communities, 37 private properties, and 2 settlements. Residents depend on Brazil Nut and Acaí collection as their primary source of income and supplement with small agriculture and breeding of domestic animals.

\section{Data Collection and Questionnaire Design}

Between April 2016 and July 2017, we used a mixed questionnaire (i.e., containing close- and open- ended questions) administered through personal-structured interviews in Santa Rosa, Tacana II, and MNAWR. We used semi-random stratified sampling to ensure maximum representation. We determined the appropriate sample size for each community within each study area based on the census information of adults (above 18 years old) available at the time, ensuring that sampling was proportional to the target population $(\sim 10 \%$ sampling

\footnotetext{
${ }^{4}$ https://wwf.panda.org/wwf_offices/bolivia/our_work/amazon_program/ pando_forests/
}

ratio). We stratified the sample by gender to ensure the equal representation of male and female voices and, in pursuit of this, attempted to interview both male and female heads of households at each home. We randomly selected respondents within each community and revisited them if no head of the household was present during the first visit. Most participants selected and interviewed were the first adult contacted in the household. No incentives were offered to those who agreed to be interviewed. Most interviews lasted between 20 and $40 \mathrm{~min}$. The survey instrument was pretested in each study area, and final adjustments were made accordingly. The questionnaire was written and conducted in Spanish and translated to English for analysis. Four of the authors (NN, KB, GG, $\mathrm{PB}$ ) conducted the interviews. We excluded potential interviewer bias a posteriori by testing for statistically significant differences in the data collected by the four interviewers.

Ethical approval was obtained from Miami University Ohio IRB for Human Subject Research, Protocol Number 03252e. Based on Marchini and Macdonald (2012) questionnaire, specific close-ended questions were designed to explore the various components of the cognitive hierarchy, such as attitudes 
and norms (see Supplementary Data Sheet 1 for the complete questionnaire). We also collected data on general demographics, experiences with jaguars, and past jaguar killing. The questions analyzed are as follows:

\section{Background Factors}

We obtained data on age, ethnic origin, gender, education, and hunting habits. Age and ethnicity were open-ended questions; education was categorical (four categories: incomplete and complete primary and secondary schooling). We measured gender with a binary question (male/female). We also asked interviewees binary questions about whether they hunt (yes/no) and whether they typically carry a gun while in the forest (yes/no). We examined ethnic origin as a background variable only in analyses of Santa Rosa because Tacana II and MNAWR were ethnically homogenous. We examined two categories of perceived impact of jaguars based on previous research in Brazil: livestock loss and jaguar attacks on humans (Marchini and Macdonald, 2012). To measure these two categories, we used two binary (yes/no) questions: (1) Has a jaguar attacked your domestic animals? (2) Have you ever been attacked, or do you know someone who was attacked by a jaguar? In addition, we asked respondents to estimate the number of jaguars within the territory of their community (open-ended) to gauge perceptions of local population size.

\section{Attitudes}

We assessed the affective and cognitive components of attitudes toward both jaguars and jaguar killing, as well as beliefs about jaguar attack prevalence and the risk of a jaguar attack in the future. The affective component of attitudes toward jaguars, "describe your feelings toward jaguars," was measured using a five-point Likert-type scale (from 1 to 5: "I don't like them at all" to "I like them a lot"). Attitudes toward jaguar killing were measured using a three-point scale, with lower values corresponding with negative evaluations of jaguar killing. Specifically, interviewees were asked to complete the following statement: in your opinion, killing a jaguar is: bad (1), neither good nor bad (2), or good (3). We assessed the cognitive component of attitudes by examining beliefs about jaguar attack prevalence using a five-point Likert-type scale [strongly disagree (1) to strongly agree (5)]. Agreement with the following statement was measured: "Jaguars kill more people every year in Bolivia than do domestic dogs $5^{5}$." We measured beliefs about risk from jaguars using a four-point scale [none (1) to high (4)] with the following question: what is the risk of you or your family being attacked by a jaguar in the coming months?

\section{Norms}

We measured normative beliefs about preferred jaguar population size in the next 5 years in the territory of their community using a six-point scale [from disappear (1) to strongly increase (6)]. Descriptive and subjective norms regarding jaguar killing were measured using five-point scales

${ }^{5}$ ACEAA unpublished data [none (1)-all (5)]. The questions were as follows: (1) How many of your neighbors do you think kill jaguars? (descriptive); (2) Among your neighbors, how many would agree that killing a jaguar is a good thing? (subjective); (3) Within your family, how many would agree that killing a jaguar is a good thing? (subjective).

\section{Past Jaguar Killing}

We asked respondents whether they (if male) or their spouse (if female) had ever killed a jaguar in the past. Responses were coded as binary (yes/no). Concerning the most recent instance of jaguar killing by them or their spouses, we asked respondents to estimate how long ago the event occurred and the reason for the killing. Length of time since the last kill was recorded as an open-ended question and then coded into four categories: $0-5,5-10,10-20$, and 20 or more years ago. Reasons for last kill were coded using descriptive categories such as "fear or self-defense," and "retaliation for depredation."

\section{Emotions}

We asked participants to imagine encountering a jaguar alone while collecting Brazil nuts or walking in the forest and asked them to describe their emotional response in such a situation (open-ended). If the participants were not answering, the interviewers prompted them by asking if they would feel afraid. We coded the open-ended answers into seven categories for analysis (bravery, fear, nervousness, no fear, positive feelings, and unsure).

\section{Data Analysis}

We accepted quantitative questionnaires for analysis if the respondent completed the demographics section, but respondents may not have answered every question. As such, sample size differs among some questions analyzed, reflecting the number of responses to that question. To compare results among geographic areas, we calculated means, medians, standard deviations, and frequency data for each variable. To test for significant differences in responses among areas, we used logistic regression for binary responses and ordinal logistic regressions for responses on the Likert-type scale. For all analyses, we set MNAWR as the reference category and used Akaike's Information Criterion (AIC) and a likelihood ratio (LR) test to determine whether a variable was significant.

We examined the relationship between several predictor variables (background factors, attitudes, and norms) and attitudes toward jaguars and toward killing jaguars using an ordinal logistic regression. We used backward stepwise variable selection based on AIC to find the most parsimonious model. We also analyzed the effect of the same predictor variables on past jaguar killing using a logistic regression and the same strategy for variable selection. We considered results with $95 \%$ confidence intervals $(p<0.05)$ significant. All analyses were carried out in R 3.6.0 (R Development Core Team, 2019) using the ordinal package (Christensen, 2019). 


\section{RESULTS}

\section{Background Factors Demographic Variables}

We conducted interviews with a total of 533 people (response rate $=99.81 \%$ ), 224 in Santa Rosa, 137 in Tacana II, and 169 in MNAWR. However, due to missing values in the data, the sample size may be smaller for specific analyses outlined below. Mean age $(38.56, \mathrm{SD}=14.10)$ and gender distribution (55.43\% male) did not differ significantly among the three areas (Age: One-way ANOVA $F=2.84, p=0.059, \eta=0.104$; Gender: $N=531$, LR $X^{2}$ $=2.84, p=0.242$ ). In Santa Rosa, nearly a third of the population was Andean and the rest Amazonian. In Tacana II and MNAWR, nearly all respondents were Amazonian. Most (95.59\%) Tacana II residents said they hunt, a significantly higher proportion than in Santa Rosa (69.18\%) and MNAWR (66.27\%) $\left(N=461, \operatorname{LR} X^{2}\right.$ $=51.1, p<0.001, \mid=0.299)$. Also, significantly more people in Tacana II (78.20\%) reported carrying a gun when in the forest than in Santa Rosa (47.80\%) and MNAWR (37.31\%) $(N=426$, LR $\left.X^{2}=51.19, p<0.001\right)$ (Table 1).

\section{Experiences With Jaguars}

Twice as many people reported experiencing or knowing someone who had experienced a jaguar attack in Tacana II (30.88\%) as in Santa Rosa (15.45\%) and MNAWR (14.20\%) (N $\left.=525, X^{2}=15.58, p<0.001\right)$. About twice as many people said jaguars had attacked their domestic animals in the past in MNAWR (50.30\%) as in Santa Rosa $(24.43 \%)$ and Tacana II (25.55\%) $\left(N=527\right.$, LR $\left.X^{2}=32.8, p<0.001\right)$ (Table 1).

\section{Perceptions of Jaguar Abundance}

When asked to give an open-ended estimate of the number of jaguars in the area, participants in Tacana II perceived a population of 272 jaguars $(S D=233.5$, range $20-2,000)$ on average. This mean estimate was significantly higher than the average perception in Santa Rosa (31.57 jaguars; SD = 58.53; range 1-500; Tukey's $p<0.001)$ and in MNAWR (81.42 jaguars; $\mathrm{SD}=176.7$; range $1-1,000$; Tukey's $p<0.001)$. Although the difference in the perceived number of jaguars was relatively smaller between MNAWR and Santa Rosa, it was still statistically significant (Tukey's $p=0.0329$ ) (Table 1 ).

\section{Attitudes Jaguars}

Overall, nearly half (48.9\%) of those interviewed strongly disliked or disliked jaguars; almost a third (26.8\%) felt neutral. Ordinal logistic regression found no significant difference in feelings toward jaguars among the three areas $\left(N=530, \operatorname{LR} X^{2}=1.95\right.$, $p=0.377$ ) (Table 1). However, a chi-square analysis of responses revealed that the proportions of positive, negative, and neutral feelings toward the species varied among regions. About a third of residents in Santa Rosa (34.4\%) and MNAWR (29.6\%) felt neutral about jaguars. In contrast, attitudes in Tacana II were significantly more polarized $\left(\operatorname{LR} X^{2}=58.891, p<0.001\right)$, and only $10.9 \%$ felt neutral toward jaguars.

\section{Jaguar Killing}

Ordinal logistic regression revealed significantly more positive attitudes toward killing jaguars in Tacana II $(\beta=0.816, p<$ $0.001)$ and more negative attitudes in Santa Rosa $(\beta=-0.690$,

TABLE 1 | Descriptive statistics for background factors, attitudes, and norms in Santa Rosa del Abuná (Santa Rosa, $n=224)$, Tacana II $(n=137)$, and Manuripi National Amazon Wildlife Reserve (MNAWR, $n=169$ ); with significant results from ANOVA and ordinal linear regressions indicated.

\begin{tabular}{|c|c|c|c|c|}
\hline & Variable & Santa Rosa & Tacana II & MNAWR \\
\hline \multirow[t]{9}{*}{ Background factors } & Demographics & & & \\
\hline & Gender (\% male) & $58.93 \%$ & $49.64 \%$ & $54.44 \%$ \\
\hline & Mean age (years) & $37.85(\mathrm{SD}=13.26)$ & $37.1333(\mathrm{SD}=13.82)$ & $40.65(S D=15.21)$ \\
\hline & Hunt & $69.18 \%$ & $95.59 \% \%^{\star \star \star}$ & $66.27 \%$ \\
\hline & Gun-carrying & $47.80 \%$ & $78.20 \% \%^{\star \star \star}$ & $37.31 \%$ \\
\hline & Experiences & & & \\
\hline & Attacks on humans & $15.45 \%$ & $30.88 \%$ *** & $14.20 \%$ \\
\hline & Attacks on domestic animals & $24.43 \%$ & $25.55 \%$ & $50.30 \%$ *** \\
\hline & Median perceived jaguar abundance (individuals) & 10 (range: $1-500)^{\star \star \star}$ & 300 (range: $20-2,000)^{\star \star \star}$ & 20 (range: 1-1,000)* \\
\hline \multirow[t]{5}{*}{ Attitudes (General) } & Beliefs & & & \\
\hline & Jaguar attacks & $2.62(\mathrm{SD}=1.17)$ & $3.12(\mathrm{SD}=1.27)^{*}$ & $2.80(\mathrm{SD}=1.30)$ \\
\hline & Risk & $2.17(\mathrm{SD}=1.15)$ & $2.12(\mathrm{SD}=1.00)$ & $1.97(\mathrm{SD}=0.85)$ \\
\hline & Feelings & & & \\
\hline & Jaguars & $2.58(\mathrm{SD}=0.91)$ & $2.53(\mathrm{SD}=1.31)$ & $2.68(\mathrm{SD}=1.14)$ \\
\hline \multirow[t]{3}{*}{ Norms } & Normative beliefs & $2.99(\mathrm{SD}=1.41)$ & $2.95(\mathrm{SD}=0.97)$ & $3.10(\mathrm{SD}=1.24)$ \\
\hline & Descriptive & $1.57(\mathrm{SD}=0.79)^{\star \star \star}$ & $2.05(\mathrm{SD}=0.58)^{\star \star \star}$ & $1.77(\mathrm{SD}=0.49)^{\star \star \star \star}$ \\
\hline & Subjective & $2.71(\mathrm{SD}=1.32)^{\star \star \star}$ & $3.19(\mathrm{SD}=1.42)^{\star \star \star}$ & $1.99(\mathrm{SD}=0.83)^{\star \star \star}$ \\
\hline Attitudes (Specific) & Jaguar killing & $1.91(\mathrm{SD}=0.76)^{\star \star}$ & $2.25(\mathrm{SD}=0.76) \mathrm{s}^{\star \star \star}$ & $2.12(\mathrm{SD}=0.76)^{\star \star}$ \\
\hline Behavior & Past killing & $20.39 \% *$ & 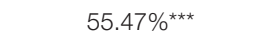 & $32.72 \% *$ \\
\hline
\end{tabular}

${ }^{\star} p<0.05,{ }^{\star \star} p<0.01,{ }^{\star \star \star} p<0.001$. 
$p<0.01)$ than in the reference category MNAWR $(N=533, \mathrm{LR}$ $X^{2}=56.10, p<0.001$ ) (Table 1; Figure 2).

\section{Human Casualties From Jaguar Attacks}

Beliefs about the prevalence of human casualties from jaguar attacks in Bolivia differed among the areas $\left(N=519\right.$, LR $X^{2}$ $=13.14, p=0.001)$. In Santa Rosa, people were more likely to disagree with the incorrect statement "jaguars kill more people than dogs kill in Bolivia each year," than people in Tacana II and MNAWR, although the effect of area on beliefs was not significant $(\beta=0.237, p=0.210)$. In contrast, residents of Tacana II were less sure of the statement's truth-value $(\beta=-0.479, p=$ 0.026 ), and residents of MNAWR fell in the middle of the two (Table 1).

\section{Future Risk of Attack on Humans}

In general, people believed the risk of a jaguar attack in the future was low (Table 1). There were no statistical differences in beliefs about risk among areas $\left(N=503, \operatorname{LR} X^{2}=1.39, p=0.499\right)$.

\section{Norms}

\section{Normative Beliefs}

In all three areas, people thought jaguar populations should decrease slightly (Table 1). There was no difference in normative beliefs about jaguar population size among the three areas $(N=$ 526, LR $\left.X^{2}=3.76, p=0.153\right)$.

\section{Descriptive Norms}

People in Tacana II thought a significantly higher proportion of their neighbors kill jaguars than people in the other two areas perceived in their respective communities $(\beta=0.945$, $p<0.001)$. In Santa Rosa, a significantly lower proportion thought their neighbors kill jaguars $(\beta=-1.014, p<0.001)$ while MNAWR was in the middle $\left(N=517\right.$, LR $X^{2}=69.61$, $p<0.001)$.

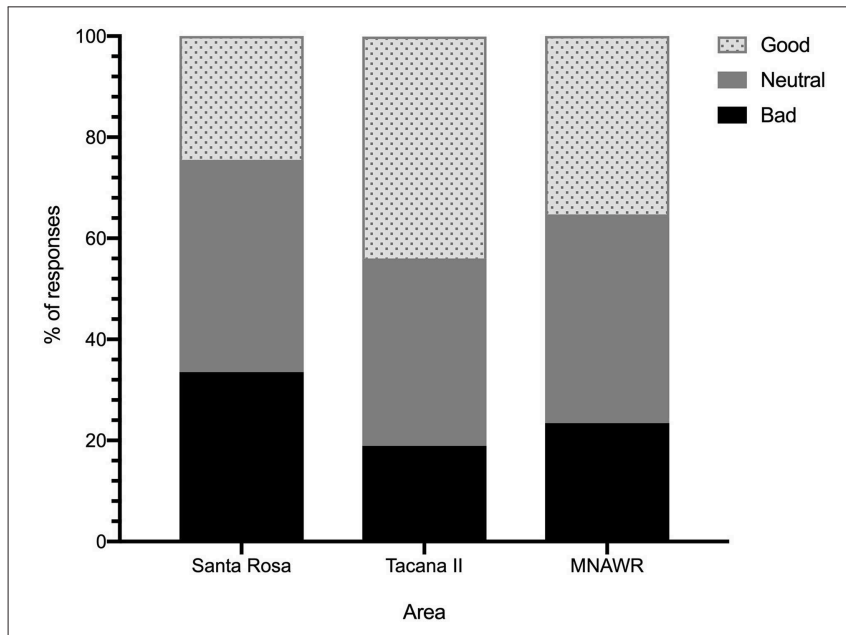

FIGURE 2 | Proportions of attitudes toward jaguar killing, by area.

\section{Subjective Norms}

Following the trend of descriptive norms, people in Tacana II thought significantly more of their neighbors approved of killing jaguars than people in the other two areas perceived in their communities $(\beta=1.714, p<0.001)$. However, although descriptive norms indicated increased perceptions of jaguar killing in MNAWR compared to Santa Rosa, subjective norms about the behavior were flipped. Santa Rosa residents thought more of their neighbors would approve of the behavior $(\beta=$ $0.980, p<0.001)$ than MNAWR residents $\left(N=501, \operatorname{LR} X^{2}=\right.$ 57.39, $p<0.001)$.

\section{Jaguar Killing}

There were significant differences in jaguar killings among regions $\left(N=451\right.$, LR $\left.X^{2}=39.75, p<0.001\right)$. Over half $(55.47 \%)$ of Tacana II reported killing a jaguar in the pasta proportion significantly higher $(\beta=0.941, p<0.001)$ than those of Santa Rosa and MNAWR. Nearly a third $(32.72 \%)$ of MNAWR described past killing, significantly more than Santa Rosa, where about a fifth of interviewed residents (20.39\%) reported the behavior $(\beta=-0.640, p=0.014$, Table 1; Figure 3). More than half $(63.4 \%)$ of the respondents $(N=142)$ who had killed a jaguar in the past killed one within the last 5 years. Fewer people most recently killed a jaguar between 5 and 10 years ago $(12.7 \%)$, between 10 and 20 years ago (16.2\%), or more than 20 years ago (7.2\%) (Supplementary Table F). When asked why they most recently killed a jaguar, 65.5\% mentioned fear, $17.9 \%$ retaliation, $6.9 \%$ trade, and $5.5 \%$ said it was accidental (Supplementary Table G).

\section{Emotions}

The two most common emotions mentioned by participants $(N=530)$ when asked how they would feel if they saw a jaguar in the forest were fear (67.5\%) and no fear $(25.1 \%)$. Respondents rarely mentioned positive feelings $(0.8 \%)$, bravery

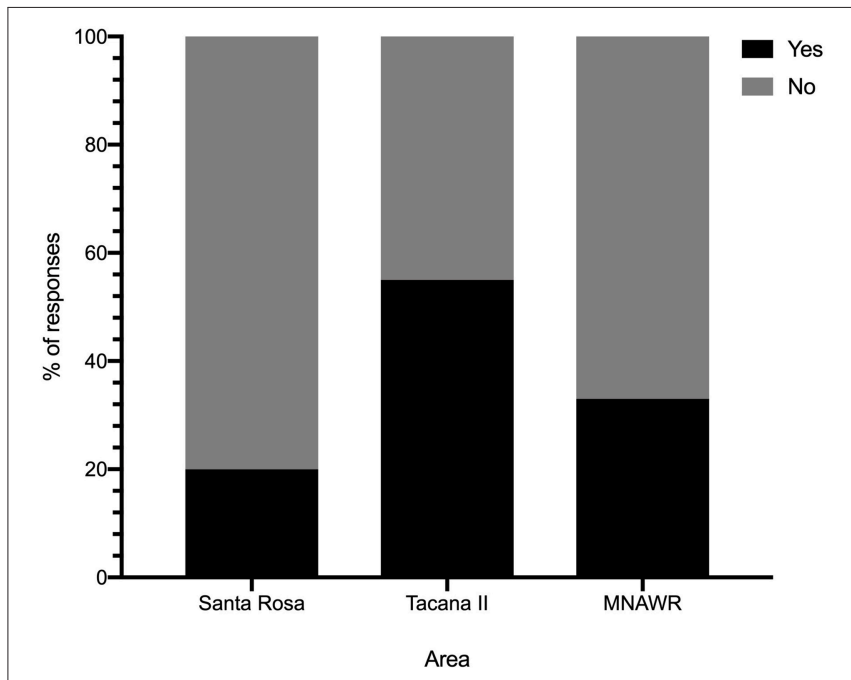

FIGURE 3 | Proportion of residents who reported killing a jaguar in the past, by area. 
(2.3\%), or nervousness $(0.9 \%)$, and few people were unsure of their emotions (3.4\%) (Supplementary Table A). Given the low number of responses for most categories, we only looked at fear and no fear for further analyses. We used a logistic regression model to look at differences in these two emotions across gender and study areas. We used no fear as the reference category as it was the most neutral response. Model selection indicated that both gender and area were significant for explaining fear but that there was no interaction. Women felt more frequently afraid than men $(\beta=2.325, p<0.001)$ and people in Santa Rosa $(\beta=0.909, p<0.001)$ and people in Tacana II $(\beta=0.784, p$ $<0.010$ ) were more afraid than people in MNAWR (Figure 4; Supplementary Table B).

\section{Factors Affecting Attitudes Toward Jaguars}

Three main factors were correlated with attitudes toward jaguars ( $N=355$ interviews): gender, beliefs about the prevalence of human casualties from jaguar attacks, and subjective norms regarding jaguar killing. Gender correlated with attitudes such that women had more negative attitudes toward jaguars than men $\operatorname{did}(\beta=-0.682, p=0.001)$. In addition, people who believe that jaguars kill more people than dogs do were more negative toward jaguars $(\beta=0.248, p=0.003)$ than those who did not believe this. People who perceived their family members as approving of jaguar killing also had more negative attitudes toward jaguars ( $\beta$ $=-0.249, p<0.001)$. Study area was not significant and did not appear in the highest-ranking model (Supplementary Table C).

\section{Factors Affecting Attitude Toward Killing Jaguars}

The highest-ranking predictive model included three factors that correlate with a person's attitude toward killing jaguars $(N=$ 355 interviews). The first factor, was having been attacked by a jaguar or knowing someone who has been attacked by a jaguar, was a strong determinant of positive feelings about killing jaguars $(\beta=1.036, p<0.001)$. Two measures of subjective norms regarding jaguar killing, family members' $(\beta=0.235, p$ $=0.007)$ and neighbors' approval $(\beta=0.310, p=0.004)$ of the action, were also strong determinants of positive attitudes toward killing jaguars. There was a significant difference in attitude toward killing jaguars among the three study areas, with people in Santa Rosa more likely to evaluate killing jaguars as bad $(\beta=-1.424, p<0.001)$ compared to the other two areas (Supplementary Table D).

\section{Factors Affecting Past Jaguar Killings}

Several factors were correlated with whether a person had killed a jaguar in the past ( $N=355$ interviews). Older people were more likely to have killed a jaguar in the past $(\beta=0.7711, p<$ $0.001)$, and so were people who regularly hunt $(\beta=0.485, p=$ $0.153)$. People who had experienced a jaguar attack $(\beta=0.597$, $p<0.072)$ or had their domestic animals attacked by a jaguar $(\beta$ $=0.858, p<0.001$ ) were also more likely to have killed a jaguar, as were people who perceived their families as feeling favorably toward jaguar killing $(\beta=0.338, p<0.001)$. The proportion of respondents who had killed a jaguar in the past was different among study areas, with Tacana II being higher $(\beta=-1.424, p$ $<0.001)$ and Santa Rosa lower $(\beta=-1.424, p<0.001)$ than the reference category MNAWR (Supplementary Table E).

\section{DISCUSSION}

\section{Attitudes Toward Jaguars and Jaguar Killing}

Our results revealed negative perceptions of jaguars in the context where cattle depredation by jaguars in not an issue. Overall, people in the protected territories addressed in this study either disliked or felt neutral toward jaguars. Negative attitudes toward jaguars are not uncommon (Zimmermann et al., 2005; Cavalcanti et al., 2010; Castaño-Uribe et al., 2016; Porfirio et al., 2016), but are often attributed to livestock loss and resulting economic cost (Rosas-Rosas and Valdez, 2010; Parker et al., 2014; Amit and

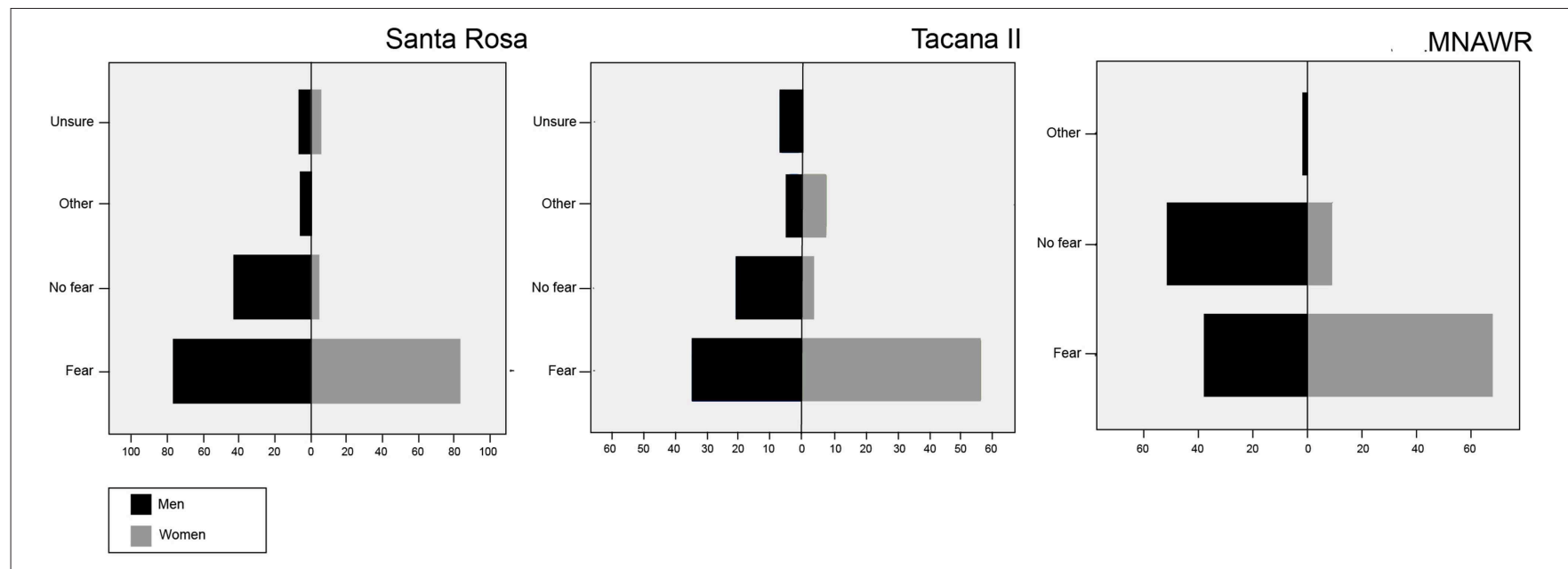

FIGURE 4 | Proportion of men and women fear to encounter jaguars, by area. 
Jacobson, 2017). However, fear and opportunistic encounters, as reported by participants in this study, can also increase negative attitudes (Cavalcanti et al., 2010; Castaño-Uribe et al., 2016). Perceptions of jaguars in indigenous communities vary across studies. For instance, Steinberg (2016) reported negative perceptions of jaguars in Mayan hunters in Belize while Figel et al. (2011) described positive attitudes toward the large carnivore in indigenous/community-conserved areas of Mexico. Finally, Kelly (2019) conveyed that Cabécar from Costa Rica had more conflicts with felines than the Ticos (non-indigenous counterparts).

Despite legal restrictions on jaguar killing across the species' range, persecution by humans is a significant threat to the species (Zeller, 2007; Galetti et al., 2013). Our results indicate that jaguar killing is relatively common in northern Bolivia. In Tacana II, over half of interviewees said either they or their spouse had killed at least one jaguar. Similar to other studies (Carvalho and Pezzuti, 2010; Carvalho, 2019), people talked about this behavior openly. This willingness to share this information may account for the higher descriptive and subjective norms concerning jaguar killing in the Tacana II study area. Fewer people said they had killed a jaguar in the past in Santa Rosa (20.39\%) and MNAWR (32.72\%), but respondents in both areas still perceived jaguar killing as relatively common, and people made little attempt to keep it secret. Overall, people who had killed jaguars had last done so relatively recently; with more than half saying, they killed a jaguar within the last 5 years. Jaguar persecution without cattle loss has been reported elsewhere (Jędrzejewski et al., 2017; Bredin et al., 2018), indicating that killing is not solely retaliatory. Considering the recent reports of trafficking of jaguar parts in Bolivia (Nuñez and Aliaga-Rossel, 2017) and the relatively high levels of jaguar killing reported in our interviews, persecution of jaguars likely represents a significant threat to jaguar survival in northern Bolivia.

\section{Attacks on Humans: Beliefs, Fear, and Risk Evaluations}

Jaguar attacks on humans are remarkably rare compared to other large felids (Marchini and Luciano, 2009; Neto et al., 2011). Nevertheless, significant proportions of interviewees in each area said they had experienced or knew someone who had experienced a jaguar attack (Santa Rosa: 15.45\%, MNAWR: $14.20 \%$, Tacana II: $30.88 \%$ ). This finding is not unheard of: in the Pantanal, nearly a third $(29.5 \%)$ of interviewees said they had heard of a jaguar attack (Santos et al., 2008) despite the only documented, fatal attack by a jaguar on a human in Brazil occurring later that year (June 24, 2008). In southwestern Bolivia, nearly half of ranchers interviewed in 2011 considered large felids a threat to human safety (Conforti and De Azevedo, 2003; Porfirio et al., 2016; Villalva and Palomares, 2019). Given the discrepancy between evidence of jaguar attacks on humans and the proportion of interviewees who reported experiencing or knowing someone who had experienced a jaguar attack, nonconfrontational encounters with the species may incite enough fear in residents to be described as attacks. It is also possible that our results reflect a common story about a notable past attack in the region. During interviews, respondents mentioned a story about a young man who was attacked by a jaguar while collecting Brazil Nuts. However, the origin of the story was unclear since, in the different areas, people claimed the attack occurred in their region. Stories, or myths, are intertwined with our beliefs, values, actions (Gottschall, 2012; Fort et al., 2018). Hearing stories about a jaguar attack may influence jaguar killing, as fear of large carnivores can be incited through knowledge of an attack (Dickman, 2010; Kelly, 2019) and the perception of the jaguar as threatening to humans is associated with attitudes toward jaguar killing in the Amazon (Carvalho, 2019).

In any case, the relatively large number of interviewees who reported a supposed attack on themselves or someone they know is concerning for jaguar survival in northern Bolivia. Similarly to other studies (Kellert and Berry, 1987; Røskaft et al., 2003; Johansson et al., 2012), female respondents reported more fear of the large carnivore than male respondents reported. Fear has been shown to affect intention to kill jaguars (Marchini and Macdonald, 2012; Engel et al., 2016) and other large carnivores (Flykt et al., 2013), and our findings support this association. Most respondents who had killed a jaguar in the past said they did so out of fear or self-defense. Fear is the most relevant emotion toward large carnivores (Johansson et al., 2012; Jacobs and Vaske, 2019) and has negatively affected the way people experience wildlife (Engel et al., 2016; Kelly, 2019). Reported jaguar attacks on humans were related to both attitudes toward killing and killing behavior, although the nature of that relationship differed by region and type of experience. In Santa Rosa and Tacana II, respondents who reported a supposed jaguar attack on themselves or someone they know were more supportive of killing and more likely to have killed jaguar in the past. The similar influence of attack experiences on jaguar killing between Santa Rosa and Tacana II is interesting, given their differing numbers of attack experiences and past jaguar killing. Twice as many people in Tacana II reported past attack experiences compared to reports in Santa Rosa. In addition, far more respondents in Tacana II said they had killed a jaguar than in Santa Rosa. An association between experiencing a wildlife attack and low tolerance of the species responsible has been shown with other large carnivores, like tigers (Inskip et al., 2016).

Despite the significant number of interviewees that reported experiencing or knowing someone who had experienced an attack, people in all three areas believed the risk of a future jaguar attack was low (Table 1). This discrepancy between reported attack experiences and perceptions of future risk contradicts the logical association between risk perception and past experience, which has been shown in relation to carnivores (Lute and Gore, 2019). However, a similar discrepancy between negative experiences with jaguars and the perceived impact of jaguars on human safety was noted by Marchini and Macdonald (2018) in Amazonia and in the Pantanal. We hypothesize that this discrepancy could be due to the way in which we assessed perceived risk. Of the two constructs of risk perception, we examined the cognitive one by measuring the perceived probability of future jaguar attacks, which can only partially explain human behavior toward large carnivores (Sjöberg, 1998; Lute and Gore, 2019). The relationship we found between experiencing or hearing about a jaguar attack on humans and 
past jaguar persecution, despite low cognitive risk perceptions in all three areas, is indicative of this. Thus, our results support the need to include measurements of the affective component of risk perception (e.g., dread, worry) in studies of the relationship between perceived risk and behavior toward large carnivores.

\section{Drivers of Jaguar Persecution}

In our study, predictors of jaguar killing and attitudes toward this behavior differed in character and effect size among the three study areas. Our findings, like previous studies on regional diversity in determinants of intention to kill jaguars (Marchini and Macdonald, 2012) and perceptions of jaguars (Santos et al., 2008), highlight the need for regionalized conservation interventions.

\section{The Importance of Stakeholder Characteristics}

In general, more demographic variables were related to attitudes toward jaguar killing than were associated with the behavior itself. The effect of demographics varied by region: for example, only gender was related to behavior in Tacana II and MNAWR. In all three-study areas, however, women were less positive about jaguars than men and evaluated jaguar persecution more favorably. Previous studies have indicated a similar gender difference in tolerance of large carnivores (Kellert and Berry, 1987; Campbell and Alvarado, 2011; Harvey et al., 2017; Mkonyi et al., 2017). Age was a significant predictor of past jaguar killing in MNAWR, but not in the other two areas. It might be that older people were more likely to have killed a jaguar in the past than younger people were, given that they have lived with jaguars for longer. However, it is also possible that this relationship reflects changing behavior toward jaguars. Some studies have indicated that attitudes toward wildlife are becoming more positive in some segments of the populations, possibly due to societal shifts such as urbanization and education (Manfredo et al., 2003, 2009; Sponarski et al., 2013).

In Santa Rosa, ethnic origin influenced attitudes toward killing and past behavior. Contrary to Tacana II and MNAWR, the sample population in Santa Rosa included two different ethnic origins: Amazonian (like Tacana II and MNAWR) and Andean. Andean participants held more positive attitudes toward jaguars than Amazonian residents did. The influence of ethnic origin on tolerance may be due to less experience with the predator. The people of Andean origin in Santa Rosa come from a different socio-ecological context, and more are farmers. They began coexisting with jaguars relatively recently when they arrived in Santa Rosa less than a decade ago. The Andean population in Santa Rosa may explain the lower rates of perceived attack experience and reported jaguar killing in Santa Rosa compared to Tacana II and MNAWR, as they have lived with jaguars for far less time than the Amazonian population. However, our findings contradict those of previous studies that have found long-term exposure to large carnivore-related risks leads to more positive attitudes toward the species (Røskaft et al., 2003; Mkonyi et al., 2017; Glikman et al., 2019). Cultural differences between Amazonian and Andean social groups may also play a role. Sociocultural influences can be significant determinants of attitudes toward carnivore management (Lute et al., 2014) and norms regarding livestock protection (Hazzah et al., 2009). Studies have also indicated that sociocultural factors can affect behavior toward large carnivores, including intention to kill wild cats (Harvey et al., 2017), intention to kill jaguars (Marchini and Macdonald, 2012), retaliatory killing of wolves (Mishra, 1997), and retaliatory killing of bears (Liu et al., 2011).

\section{Experiences: Perceived Attacks and Depredation}

The effect of livestock loss on attitudes toward carnivores varies between studies and contexts, with some reporting a strong relationship (Dickman, 2008; Kissui, 2008) and others no direct relationship at all (Conforti and De Azevedo, 2003; Mkonyi et al., 2017). Experiencing or knowing someone who experienced a perceived jaguar attack on humans predicted jaguar killing in Santa Rosa and Tacana II. Jaguar attacks on domestic animals were also related to persecution in all three areas. However, the effect of depredation on killing was minimal, and only Tacana II was the experience a significant predictor of jaguar persecution. Jaguars represent a significant and well-documented threat to livestock throughout their range (Crawshaw, 2004; Zimmermann et al., 2005; Cavalcanti et al., 2010; Marchini and Macdonald, 2012; Amit et al., 2013; Amit and Jacobson, 2017), and perceived impact on livestock is a predictor of intent to kill jaguars for cattle ranchers in Brazil (Marchini and Macdonald, 2012). Our results show a smaller relationship between domestic animal loss and persecution than that shown in the Brazilian Amazonia and Pantanal (Marchini and Macdonald, 2012) and other cattle-ranching populations (Jędrzejewski et al., 2017). This difference in magnitude may be because domestic animals are not the primary livelihood for people living in and around the northwestern Bolivian Amazon. Our findings show transcendence of the effect of depredation on killing behavior beyond livestock-reliant populations, albeit to a smaller degree.

\section{Attitudes}

In all three-study areas, attitudes toward jaguars were generally unrelated to past jaguar killing. More surprisingly, attitude toward jaguar killing was also unrelated to killing jaguars in the past, in contrast to research indicating attitude toward jaguar persecution as a predictor of intention to kill jaguars (which has been empirically linked to the action of killing jaguars; Marchini and Macdonald, 2012). Currently, our results indicate that conservation strategies focused on changing attitudes toward jaguars and jaguar persecution may not be effective in this region of Bolivia. However, considering that attitudes toward large carnivores can change over time (Majić and Bath, 2010; Majić et al., 2011), continued monitoring of the relationship between attitudes and jaguar killing would be prudent.

\section{Norms}

Norms regarding acceptable behavior in a social group can govern actions toward wildlife independently of legal restrictions (Gore et al., 2013; Hazzah et al., 2014). In Brazil's Pantanal region, for example, the Pantaneiro identity is linked to jaguar persecution because of the normative belief that the behavior is common and acceptable within the social group (Marchini and Macdonald, 2012). Social motivations were important 
determinants of attitudes toward persecution in all study areas and past killing of jaguars in different proportions among study areas. Especially in Tacana II, the proportion of people who thought their neighbors felt favorable about killing jaguars (i.e., descriptive norms) also felt favorable about this behavior and were more likely to have killed one in the past. Furthermore, the perception that jaguar killing is common and acceptable may cause more jaguars to be killed, especially if hunting stories are remembered and repeated, creating a vicious circle (Marchini and Macdonald, 2012). In addition, effect of subjective norms (i.e., perception of others approving killing jaguars) did vary by area. It had a larger influence on attitudes toward jaguar killing in Tacana II than in Santa Rosa and MNAWR.

\section{Future Jaguar Conservation Strategies}

In northwest Bolivia, local indigenous people are living and working close to jaguars. This proximity is both a risk and an opportunity for jaguar conservation. On the one hand, if conservation efforts do not succeed, the close relationship local people have with jaguars could be a considerable threat to the species' survival. On the other hand, the support and involvement of local communities can aid conservation interventions, and their presence sometimes protects wildlife populations. In this study, we generally show negative attitudes toward jaguars in northwest Bolivia and rates of self-reporting past jaguar killing that raise concern. Given the increased jaguar trafficking in Bolivia over the past few years (Nuñez and Aliaga-Rossel, 2017), these results corroborate an urgent need for jaguar conservation in Bolivia. The current lack of tolerance for jaguars, combined with increasing pressure from development, a burgeoning jaguar trade, and Chinese immigration into the area, can create an atmosphere conducive to widespread jaguar killing.

The jaguar is important to Bolivia, culturally, symbolically, and economically (through tourism dollars). Furthermore, the relationship between subjective norms and both attitudes toward killing and past killing of jaguars found in this study shows the power of social influence. People who felt their neighbors disapproved of killing jaguars felt worse about the action themselves and were less likely to have killed a jaguar in the past. As such, the importance of attitudes toward wildlife, although often characterized as essential to wildlife conservation success (Wang et al., 2006; Palmeira et al., 2008; Ogra, 2009; Hariohay et al., 2018), may not apply to communities in northern Bolivia.

In all three study areas, attitudes toward jaguars and killing jaguars were both unrelated to whether an individual killed a jaguar in the past. Thus, how people perceive their communities feel about killing jaguars may be more important as a conservation target than how individuals themselves evaluate the behavior. This finding is significant to conservation because social norms can be changed. For example, conservation efforts targeting well-respected individuals or institutions in a community can influence the social acceptability of specific behaviors (Veríssimo, 2013; Veríssimo and McKinley, 2016; Jones et al., 2019; Marchini and Macdonald, 2019). Furthermore, measurements of conservation success may need to include levels of persecution, rather than solely attitudes and beliefs, even though the behavior can be a more sensitive topic given legal regulations and potential consequences.

\section{Further Research}

This study should be seen as an exploration of human-jaguar relationships in a little-studied setting-non-cattle ranching communities in legally-protected territories of the northern Bolivian Amazon. Our findings, especially those indicating high levels of jaguar killing and perceived jaguar attacks on humans, support the urgent need for further research in this area to better understand why people kill jaguars and how to prevent killing effectively. In particular, a predictive model of intention to kill jaguars would be useful for conservation efforts. One possible tool for further investigation is the Theory of Planned Behavior, which examines how attitudes, norms, and perceived behavior controls influence behavior intentions and has been used in the context of jaguar persecution in cattle-ranching communities (Marchini and Macdonald, 2012, 2018). Also, research should focus on ways to cause changes in the killing by looking at the efficacy of alternative interventions to change human behavior in human-wildlife conflict situations.

\section{CONCLUSIONS}

A combination of demographic variables, experiences, and psychological and social motivations influences attitude toward jaguars and jaguar persecution. Furthermore, their relative importance in determining attitudes and past behavior differs between areas of northern Bolivia. Our findings indicate the prevalence of jaguar persecution in northern Bolivia and highlight the need for conservation interventions. Our findings also show how specific the determinants of attitude and behavior can be to a community, how influential negative experiences with jaguars can be in determining jaguar persecution, and the power of social norms on both attitudes toward killing and the behavior itself. It would be impossible to construct an effective jaguar conservation strategy in any of our study areas based on one category of influence.

We suggest strategies to prevent jaguar killing in northern Bolivia should focus on changing social norms related to persecution and lessening negative experiences-both tangible and intangible-with the species. Lastly, this study highlights how specific the determinants of attitude and behavior can be to a population. Such variation underlines the importance of understanding the communities in which conservation interventions are employed. Therefore, a multi-stakeholder approach to conservation that includes local people in decisionmaking is essential. As the pressure of jaguars in Bolivia increases, indigenous and other communities living with jaguars in protected areas will be essential to the species survival. There is an urgent need to find ways to limit conflict surrounding jaguar conservation, change social norms toward jaguar killing, and find ways to mitigate jaguar persecution in the northwestern Bolivian Amazon so that they may continue to inhabit this area. 


\section{DATA AVAILABILITY STATEMENT}

All datasets generated for this study are included in the article/Supplementary Material.

\section{ETHICS STATEMENT}

The studies involving human participants were reviewed and approved by Miami University Ohio IRB for Human Subject Research, Protocol Number 03252e. Written informed consent for participation was not required for this study in accordance with the national legislation and the institutional requirements.

\section{AUTHOR CONTRIBUTIONS}

JK was a lead author contributing to writing all sections under the supervision of JG. JK together with NN and JG conceptualized the paper. NN and SM designed the social science methodology. $\mathrm{KB}, \mathrm{GG}$, and PB have collected the data. JG contributed writing

\section{REFERENCES}

Ajzen, I. (2001). Nature and operation of attitudes. Annu. Rev. Psychol. 52, 27-58. doi: 10.1146/annurev.psych.52.1.27

Amit, R., Gordillo-Chávez, E. J., and Bone, R. (2013). Jaguar and puma attacks on livestock in Costa Rica. Hum. Wildlife Interact. 7, 77-84. doi: $10.26077 / 885 q-4818$

Amit, R., and Jacobson, S. K. (2017). Understanding rancher coexistence with jaguars and pumas: a typology for conservation practice. Biodivers. Conserv. 26, 1353-1374. doi: 10.1007/s10531-017-1304-1

Azevedo, F. C. C., and Murray, D. L. (2007). Evaluation of potential factors predisposing livestock to predation by jaguars. J. Wildlife Manage. 71, 2379-2386. doi: 10.2193/2006-520

Bredin, Y. K., Lescureux, N., and Linnell, J. D. (2018). Local perceptions of jaguar conservation and environmental justice in Goias, Matto Grosso and Roraima states (Brazil). Global Ecol. Conserv. 13:e00369. doi: 10.1016/j.gecco.2017.e00369

Campbell, M. O., and Alvarado, M. E. T. (2011). Public perceptions of jaguars Panthera onca, pumas Puma concolor and coyotes Canis latrans in El Salvador. Area 43, 250-256. doi: 10.1111/j.1475-4762.2011.00996.x

Carter, N., Riley, S., and Liu, J. (2012). Utility of a psychological framework for carnivore conservation. Oryx 46, 525-535. doi: 10.1017/S0030605312000245

Carter, N. H., and Linnell, J. D. C. (2016). Co-adaptation is key to coexisting with large carnivores. Trends Ecol. Evol. 31, 575-578. doi: 10.1016/j.tree.2016.05.006

Carvalho, E. A. (2019). Jaguar hunting in amazonian extractive reserves: acceptance and prevalence. Environ. Conserv. 46, 334-339. doi: $10.1017 /$ S0376892919000274

Carvalho, E. A. R. Jr., and Pezzuti, J. C. B. (2010). Hunting of jaguars and pumas in the Tapaj'os-arapiuns extractive reserve, brazilian amazonia. Oryx 44, 610-612. doi: $10.1017 /$ S003060531000075X

Castaño-Uribe, C., Lasso, C., Hoogesteijn, R., Díaz, A., and Payán, E. (2016). Conflicto Entre Felinos y Humanos en América Latina, Editado por Carlos Lasso. Vol. 2. Serie Fauna Silvestre Neotropical. Bogotá: Fundación Herencia Ambiental Caribe, Panthera Colombia, Instituto de Investigaciones Biológicas Alexander von Humboldt.

Cavalcanti, S., Marchini, S., Zimmermann, A., Gese, E., and Macdonald, D. (2010). "Jaguars, livestock, and people in Brazil: realities and perceptions behind the conflict," in Biology and Conservation of Wild Felids, eds D. W. Macdonald and A. J. Loveridge (Oxford, UK: Oxford University Press), 383-402.

Christensen, R. H. B. (2019). Ordinal - Regression Models for Ordinal Data. R package version 2019.4-25. Available online at: http://www.cran.r-project.org/ package $=$ ordinal/ the theoretical background and method sections. MT contributed writing the introduction, the discussion, run all the analyses for the revised version and produced the map. All authors assisted with multiple rounds of editing and approved publication.

\section{FUNDING}

Funds for this project were provided by ACEAA-Conservación Amazónica, La Paz, Bolivia. Thanks are due to FCT/MCTES for the financial support to CESAM (UID/AMB/50017/2019), through national funds. Funds for open access publication fees were provided by Institute for Conservation Research, San Diego Zoo Global, San Diego, California, USA.

\section{SUPPLEMENTARY MATERIAL}

The Supplementary Material for this article can be found online at: https://www.frontiersin.org/articles/10.3389/fevo. 2019.00494/full\#supplementary-material

Cialdini, R. B., Reno, R. R., and Kallgren, C. A. (1990). A focus theory of normative conduct: recycling the concept of norms to reduce littering in public places. $J$. Pers. Soc. Psychol. 58, 1015-1026. doi: 10.1037//0022-3514.58.6.1015

Conforti, V. A., and De Azevedo, F. C. C. (2003). Local perceptions of jaguars (Panthera onca) and pumas (Puma concolor) in Iguaçu National Park area, south Brazil. Biol. Conserv. 11, 215-221. doi: 10.1016/S0006-3207(02) 00277-X

Crawshaw, P. G. (2004). Depredation of domestic animals by large cats in Brazil. Hum. Dimens. Wildlife 9, 329-330, doi: 10.1080/10871200490505774

de la Torre, J. A., González-Maya, J. F., Zarza, H., Ceballos, G., and Medellín, R. A. (2017). The jaguar's spots are darker than they appear: assessing the global conservation status of the jaguar Panthera onca. Oryx 52, 300-315. doi: $10.1017 /$ S0030605316001046

Dickman, A. J. (2008). Key Determinants of Conflict between People and Wildlife, Particularly Large Carnivores, Around Ruaha National Park, Tanzania (Ph.D. thesis). University College London, London, UK.

Dickman, A. J. (2010). Complexities of conflict: the importance of considering social factors for effectively resolving human-wildlife conflict. Anim. Conserv. 13, 458-466. doi: 10.1111/j.1469-1795.2010.00368.x

Eagly, A. H., and Chaiken, S. (1993). The Psychology of Attitudes. Fort Worth, TX: Harcourt Brace Jovanovich College Publishers.

Engel, M. T., Vaske, J. J., Bath, A. J., and Marchini, S. (2016). Predicting acceptability of jaguars and pumas in the Atlantic Forest, Brazil. Hum. Dimens. Wildlife 21, 427-444. doi: 10.1080/10871209.2016.1183731

Figel, J. J., Durán, E., and Bray, D. B. (2011). Conservation of the jaguar Panthera onca in a community-dominated landscape in montane forests in Oaxaca, Mexico. Oryx 45, 554-560. doi: 10.1017/S0030605310001353

Flykt, A., Johansson, M., Karlsson, J., Lindeberg, S., and Lipp, O. (2013). Fear of wolves and bears: Physiological responses and negative associations in a Swedish sample. Hum. Dimens. Wildlife 18, 416-434. doi: 10.1080/10871209.2013.810314

Fort, J. L., Nielsen, C. K., Carver, A. D., Moreno, R., and Meyer, N. F. (2018). Factors influencing local attitudes and perceptions regarding jaguars Panthera onca and National Park conservation in Panama. Oryx 52, 282-291. doi: 10.1017/S0030605317001016

Foster, R. J., Harmsen, B. J., and Doncaster, C. P. (2010). Habitat use by sympatric jaguars and pumas across a gradient of human disturbance in Belize. Biotropica 42, 724-731. doi: 10.1111/j.1744-7429.2010.00641.x

Fraser, B. (2018). "China's lust for jaguar fangs imperils big cats", in Nature Vol. 555 (Canadian Periodicals Index Quarterly). Available online at: https://link galegroup.com/apps/doc/A529350341/CPI?u=maine_orono\&sid=CPI\&xid= 2604cbf5 (accessed July 22, 2019). 
Fulton, D. C., Manfredo, M. J., and Lipscomb, J. (1996). Wildlife value orientations: a conceptual and measurement approach. Hum. Dimens. Wildlife 1, 24-47. doi: $10.1080 / 10871209609359060$

Galetti, M., Eizirik, E., Beisiegel, B., Ferraz, K., Cavalcanti, S., Srbek-Araujo, A. C., et al. (2013). Atlantic rainforest's jaguars in decline. Science 342:930. doi: 10.1126/science.342.6161.930-a

Garcia-Alaniz, N., Naranjo, E. J., and Mallory, F. F. (2010). Human-felid interactions in three mestizo communities of the selva lacandona, chiapas, mexico: benefits, conflicts and traditional uses of species. Hum. Ecol. 38, 451-457. doi: 10.1007/s10745-010-9322-6

Glikman, J. A., Ciucci, P., Marino, A., Davis, E. O., Bath, A. J., and Boitani, L. (2019). Local attitudes toward apennine brown bears: insights for conservation issues. Conserv. Sci. Pract. 1:e25. doi: 10.1111/csp2.25

Gore, M. L., Ratsimbazafy, J., and Lute, M. L. (2013). Rethinking corruption in conservation crime: Insights from Madagascar. Conserv. Lett. 6, 430-438. doi: $10.1111 /$ conl.12032

Gottschall, J. (2012). The Storytelling Animal: How Stories Make Us Human. New York, NY: Houghton Mifflin Harcourt.

Hariohay, K. M., Fyumagwa, R. D., Kideghesho, J. R., and Røskaft, E. (2018). Awareness and attitudes of local people toward wildlife conservation in the Rungwa Game Reserve in Central Tanzania. Hum. Dimens. Wildl. 23, 503-514. doi: 10.1080/10871209.2018.1494866

Harvey, R. G., Briggs-Gonzalez, V. S., and Mazzotti, F. J. (2017). Conservation payments in a social context: determinants of tolerance and behavioural intentions towards wild cats in northern Belize. Oryx 51, 730-741. doi: $10.1017 /$ S0030605316000545

Hazzah, L., Borgerhoff, M. M., and Frank, L. (2009). Lions and warriors: social factors underlying declining African lion populations and the effect of incentive-based management in Kenya. Biol. Conserv. 142, 2428-2437. doi: 10.1016/j.biocon.2009.06.006

Hazzah, L., Dolrenry, S., Naughton, L., Edwards, C. T. T., Mwebi, O., Kearney, F., et al. (2014). Efficacy of two lion conservation programs in Maasailand, Kenya. Conserv. Biol. 28, 851-860. doi: 10.1111/cobi.12244

Hoogesteijn, R., and Chapman, C. A. (1997). Large ranches as conservation tools in the Venezuelan llanos. Oryx 31, 274-284. doi: 10.1046/j.1365-3008.1997.d01-16.x

Inskip, C., Carter, N., Riley, S., Roberts, T., and MacMillan, D. (2016). Toward human-carnivore coexistence: understanding tolerance for tigers in Bangladesh. PLoS ONE 11:e0145913. doi: 10.1371/journal.pone.0145913

Inskip, C., and Zimmermann, A. (2009). Human-felid conflict: a review of patterns and priorities worldwide. Oryx 43, 18-34. doi: 10.1017/S003060530899030X

Jacobs, M., and Vaske, J. J. (2019). "Chapter 4: understanding emotions as opportunities for and barriers to coexistence with wildlife," in HumanWildlife Interactions: Turning Conflict into Coexistence, eds B. F. Frank, J. A. Glikman, and S. Marchini (Cambridge, UK: Cambridge University Press), 65-84. doi: 10.1017/9781108235730.007

Jacobs, M. H., Vaske, J. J., and Roemer, J. M. (2012). Toward a mental systems approach to human relationships with wildlife: the role of emotional dispositions. Hum. Dimens. Wildlife 17, 4-15. doi: $10.1080 / 10871209.2012 .645123$

Jędrzejewski, W., Carreño, R., Sánchez-Mercado, A., Schmidt, K., Abarca, M., Robinson, H. S., et al. (2017). Jaguar conflicts and the relative importance of retaliatory killing and hunting for jaguar (Panthera onca) populations in Venezuela. Biol. Conserv. 209, 524-532. doi: 10.1016/j.biocon.2017.03.025

Jędrzejewski, W., Robinson, H. S., Abarca, M., Zeller, K. A., Velasquez, G., Paemelaere, E., et al. (2018). Estimating large carnivore populations at global scale based on spatial predictions of density and distribution - application to the jaguar (Panthera onca). PLoS ONE 13:e0194719. doi: 10.1371/journal.pone.0194719

Johansson, M., Karlsson, J., Eja Pedersen, E., and Flykt, A. (2012). Factors governing human fear of brown bear and wolf. Human Dimens. Wildlife 17, 58-74. doi: 10.1080/10871209.2012.619001

Jones, S., Keane, A., St John, F., Vickery, J., and Papworth, S. (2019). Audience segmentation to improve the targeting of conservation interventions for hunters. Conserv. Biol. 33, 895-905. doi: 10.1111/cobi. 13275

Kellert, S. R., and Berry, J. K. (1987). Attitudes, knowledge and behaviors toward wildlife as affected by gender. Wildl. Soc. Bull. 15, 363-371.
Kellert, S. R., Black, M., Rush, C. R., and Bath, A. J. (1996). Human culture and large carnivore conservation in North America. Conserv. Biol. 10, 977-990. doi: 10.1046/j.1523-1739.1996.10040977.x

Kelly, J. R. (2019). A sociocultural perspective: human conflict with jaguars and pumas in costa rica. Conserv. Soc. 17, 355-365. doi: 10.4103/cs.cs_17_141

Kissui, B. M. (2008). Livestock predation by lions, leopards, spotted hyenas, and their vulnerability to retaliatory killing in the Maasai steppe, Tanzania. Anim. Conserv. 11, 422-432. doi: 10.1111/j.1469-1795.2008.00199.x

Liu, F., McShea, W. J., Garshelis, D. L., Zhu, X., Wang, D., and Shao, L. (2011). Human-wildlife conflicts influence attitudes but not necessarily behaviors: factors driving the poaching of bears in China. Biol. Conserv. 144, 538-547. doi: 10.1016/j.biocon.2010.10.009

Loveridge, A. J., Wang, S. W., Frank, L. G., and Seidensticker, J. (2010). "People and wild felids: conservation of cats and management of conflicts," in Biology and Conservation of Wild Felids, eds D. W. Macdonald and A. J. Loveridge (Oxford: Oxford University Press), 161-195.

Lute, M. L., Bump, A., and Gore, M. L. (2014). Identity-driven differences in stakeholder concerns about hunting wolves. PLOS ONE 9:e114460. doi: 10.1371/journal.pone.0114460

Lute, M. L., and Gore, M. L. (2019). "Chapter 3: broadening the aperture on coexistence with wildlife through the lens of identity, risk, and morals," in Human-Wildlife Interactions: Turning Conflict into Coexistence, eds B. F. Frank, J. A. Glikman, and S. Marchini (Cambridge, UK: Cambridge University Press), 45-64. doi: 10.1017/9781108235730.006

Majić, A., and Bath, A. J. (2010). Changes in attitudes toward wolves in Croatia. Biol. Conserv. 143, 255-260. doi: 10.1016/j.biocon.2009.09.010

Majić, A., Marino, A., Huber, D., and Bunnefeld, N. (2011). Dynamics of public attitudes toward bears and the role of bear hunting in Croatia. Biol. Conserv. 144, 3018-3027. doi: 10.1016/j.biocon.2011.09.005

Manfredo, M. J. (2008). Who Cares About Wildlife?: Social Science Concepts for Exploring Human-Wildlife Relationships and Conservation Issues. New York, NY: Springer Science and Business Media.

Manfredo, M. J., and Dayer, A. A. (2004). Concepts for exploring the social aspects of human-wildlife conflict in a global context. Hum. Dimens. Wildlife 9, 317-328. doi: 10.1080/10871200490505765

Manfredo, M. J., Teel, T. L., and Bright, A. D. (2003). Why are public values toward wildlife changing? Hum Dimens. Wildlife 8, 287-306. doi: 10.1080/716100425

Manfredo, M. J., Teel, T. L., and Henry, K. L. (2009). Linking society and environment: a multilevel model of shifting wildlife value orientations in the western United States. Soc. Sci. Q. 90, 407-427. doi: $10.1111 /$ j.1540-6237.2009.00624.x

Marchini, S., and Luciano, R. (2009). Guia de convivência gente e onça. Alta Floresta: Amazonarium.

Marchini, S., and Macdonald, D. W. (2012). Predicting ranchers' intention to kill jaguars: case studies in Amazonia and Pantanal. Biol. Conserv. 147, 213-221. doi: 10.1016/j.biocon.2012.01.002

Marchini, S., and Macdonald, D. W. (2018). Mind over matter: perceptions behind the impact of jaguars on human livelihoods. Biol. Conserv. 224, 230-237. doi: 10.1016/j.biocon.2018.06.001

Marchini, S., and Macdonald, D. W. (2019). Can school children influence adults' behavior toward jaguars? Evidence of intergenerational learning in education for conservation. Ambio. doi: 10.1007/s13280-019-01230-w. [Epub ahead of print].

Mishra, C. (1997). Livestock depredation by large carnivores in the Indian TransHimalaya: conflict perceptions and conservation prospects. Environ. Conserv. 24, 338-343. doi: 10.1017/S0376892997000441

Mkonyi, F. J., Estes, A. B., Msuha, M. J., Lichtenfeld, L. L., and Durant, S. M. (2017). Local attitudes and perceptions toward large carnivores in a human-dominated landscape of Northern Tanzania. Hum. Dimens. Wildlife 22, 314-330. doi: 10.1080/10871209.2017.1323356

Negrões, N., Arise, R., Asturizaga, K., Barboza, K., Fonseca, C., Ten, S., et al. (2017). "Conflicto con jaguar (Panthera onca) en bolivia: del daño al ganado a la percepción de riesgo (conflicts with jaguar (Panthera onca) in bolivia: from cattle damage to risk perceptions)," in II. Conflicto entre felinos $y$ humanos en América Latina. Serie Editorial Fauna Silvestre Neotropical, eds C. Castaño-Uribe, C. A. Lasso, R. Hoogesteijn, and E. Payán-Garrido (Bogotá: Instituto de Investigación de Recursos Biológicos Alexander von Humboldt (IAvH)), 327-338. 
Neto, M. F. C., Neto, D. G., and Haddad, V. (2011). Attacks by jaguars (Panthera onca) on humans in Central Brazil: report of three cases, with observation of a death. Wilderness Environ. Med. 22, 130-135. doi: 10.1016/j.wem.2011.01.007

Nuñez, A., and Aliaga-Rossel, E. (2017). Jaguar fang trafficking by Chinese in Bolivia. Cat News 65, 50-51.

Ogra, M. (2009). Attitudes toward resolution of human-wildlife conflict among forest-dependent agriculturalists near Rajaji National Park, India. Hum. Ecol. 37, 161-177. doi: 10.1007/s10745-009-9222-9

Palmeira, F. B., Crawshaw, P. G. Jr., Haddad, C. M., Ferraz, K. M. P., and Verdade, L. M. (2008). Cattle depredation by puma (Puma concolor) and jaguar (Panthera onca) in central-western Brazil. Biol. Conserv. 141, 118-125. doi: 10.1016/j.biocon.2007.09.015

Parker, D. M., Whittington-Jones, B. M., Bernard, R. T. F., and DaviesMostert, H. T. (2014). Attitudes of rural communities toward dispersing african wild dogs in South Africa. Hum. Dimens. Wildlife 19, 512-522. doi: 10.1080/10871209.2014.926575

Polisar, J., Maxit, I., Scognamillo, D., Farrell, L., Sunquist, M. E., and Eisenberg, J. F. (2003). Jaguars, pumas, their prey base, and cattle ranching: ecological interpretations of a management problem. Biol. Conserv. 109, 297-310. doi: 10.1016/S0006-3207(02)00157-X

Porfirio, G., Sarmento, P., Leal, S., and Fonseca, C. (2014). How is the jaguar Panthera onca perceived by local communities along the Paraguai River in the Brazilian Pantanal? Oryx 1, 1-6. doi: 10.1017/S0030605314000349

Porfirio, G., Sarmento, P., Leal, S., and Fonseca, C. (2016). How is the jaguar Panthera onca perceived by local communities along the Paraguai river in the Brazilian Pantanal? Oryx 50, 163-168. doi: 10.1017/S.0030605314000349

R Development Core Team (2019). R: A Language and Environment for Statistical Computing. Vienna.

Ripple, W. J., Estes, J. A., Beschta, R. L., Wilmers, C. C., Ritchie, E. G., Hebblewhite, M., et al. (2014). Status and ecological effects of the world's largest carnivores. Science 343:1241484. doi: 10.1126/science.1241484

Romero-Muñoz, A., Fernández-Llamazares, Á., Moraes, M. R., Larrea-Alcázar, D. M., and Wordley, C. F. R. (2019b). A pivotal year for Bolivian conservation policy. Nat. Ecol. Evol. 3, 866-869. doi: 10.1038/s41559-019-0893-3

Romero-Muñoz, A., Torres, R., Noss, A. J., Giordano, A. J., Quiroga, V., Thompson, J. J., et al. (2019a). Habitat loss and overhunting synergistically drive the extirpation of jaguars from the Gran Chaco. Divers. Distrib. 25, 176-190. doi: 10.1111/ddi.12843

Rosas-Rosas, O. C., and Valdez, R. (2010). The role of landowners in jaguar conservation in Sonora, Mexico. Conserv. Pract. Policy 24, 366-371. doi: 10.1111/j.1523-1739.2009.01441.x

Røskaft, E., Bjerke, T., Kaltenborn, B., Linell, J. D. C., and Andersen, R. (2003). Patterns of self-reported fear towards large carnivores among the Norwegian public. Evol. Hum. Behav. 24, 184-198. doi: 10.1016/S1090-5138(03)00011-4

Sanderson, E. W., Redford, K. H., Chetkiewicz, C. L. B., Medellin, R. A., Rabinowitz, A., Robinson, J. G., et al. (2002). Planning to save a species: the jaguar as a model. Conserv. Biol. 16, 58-72. doi: 10.1046/j.1523-1739.2002.00352.x

Santos, F. R., Jacomo, A. T. A., and Silveira, L. (2008). Humans and jaguars in five Brazilian biomes: same country, different perceptions. Cat News Special Issue 4, 21-25.

Sjöberg, L. (1998). Worry and risk perception. Risk Anal. 18, 85-93. doi: 10.1111/j.1539-6924.1998.tb00918.x

Soto-Shoender, J. R., and Main, M. B. (2013). Differences in stakeholder perceptions of the jaguar Panthera onca and puma Puma concolor in the tropical lowlands of Guatemala. Oryx 47, 109-112. doi: $10.1017 /$ S003060531200107X

Sponarski, C. C., Semeniuk, C., Glikman, J. A., Bath, A. J., and Musiani, M. (2013). Heterogeneity among rural resident attitudes toward wolves. Hum. Dimens. Wildlife 18, 239-248. doi: 10.1080/10871209.2013.792022

Sponarski, C. C., Vaske, J. J., and Bath, A. J. (2015). Attitudinal differences among residents, park staff, and visitors toward coyotes in Cape Breton Highlands National Park, Nova Scotia, Canada. Soc. Nat. Res. 28, 1-13. doi: $10.1080 / 08941920.2015 .1014595$
Steinberg, M. K. (2016). Jaguar conservation in southern belize: conflicts, perceptions, and prospects among mayan hunters. Conserv. Soc. 14, 13-20. doi: $10.4103 / 0972-4923.182801$

Still, J. (2003). Use of animal products in traditional Chinese medicine: environmental impact and health hazards. Complement. Ther. Med. 11, 118-122. doi: 10.1016/S0965-2299(03)00055-4

Tejada, G., Dalla-Nora, E., Cordoba, D., Lafortezza, R., Ovando, A., Assis, T., et al. (2016). Deforestation scenarios for the Bolivian lowlands. Environ. Res. 144B, 49-63. doi: 10.1016/j.envres.2015.10.010

Terborgh, J., Lopez, L., Nuñez, P., Rao, M., Shahabudin, G., Orihuela, G., et al. (2002). Ecological meltdown in predator-free forest fragments. Science 294, 1923-1925. doi: $10.1126 /$ science. 1064397

Tobler, M. W., Carrillo-Percastegui, S. E., Zúñiga Hartley, A., and Powell, G. V. N. (2013). High jaguar densities and large population sizes in the core habitat of the southwestern Amazon. Biol. Conserv. 159, 375-381. doi: 10.1016/j.biocon.2012.12.012

Treves, A., and Karanth, K. U. (2003). Human-carnivore conflict and perspectives on carnivore management worldwide. Conserv. Biol. 17, 1491-1499. doi: 10.1111/j.1523-1739.2003.00059.x

U. S. Fish and Wildlife Service (2018). Jaguar Recovery Plan (Panthera once). U.S. Fish and Wildlife Service, Southwest Region, Albuquerque, New Mexico.

Vaske, J. J., and Donnelly, M. P. (1999). A value-attitude-behavior model predicting wildland preservation voting intentions. Soc. Nat. Res. 12, 523-537. doi: 10.1080/089419299279425

Vaske, J. J., and Whittaker, D. (2004). "Normative approaches to natural resources," in Society and natural resources: A summary of knowledge, eds M. J. Manfredo, J. J. Vaske, B. L. Bruyere, D. R. Field, and P. Brown (Jefferson, MO: Modern Litho), 283-294.

Veríssimo, D. (2013). Influencing human behaviour: an underutilised tool for biodiversity management. Conserv. Evid. 10:29e31.

Veríssimo, D., and McKinley, E. (2016). Introducing conservation marketing: why should the devil have all the best tunes? Oryx 50:14. doi: $10.1017 /$ S0030605315001180

Verplanken, B., Hofstee, G., and Janssen, H. J. (1998). Accessibility of affective versus cognitive components of attitudes. Eur. J. Soc. Psychol. 28, 23-35. doi: 10. 1002/(SICI)1099-0992(199801/02)28:1<23::AID-EJSP843>3.0.CO;2-Z

Villalva, P., and Palomares, F. (2019). Perceptions and livestock predation by felids in extensive cattle ranching areas of two Bolivian ecoregions. Eur. J. Wildlife Res. 65:36. doi: 10.1007/s10344-019-1272-8

Wang, S. W., Lassoie, J. P., and Curtis, P. D. (2006). Farmer attitudes towards conservation in Jigme Singye Wangchuck National Park, Bhutan. Environ. Conserv. 33, 148-156. doi: 10.1017/S0376892906002931

White, R. M., Fischer, A., Marshall, K., Travis, J. M., Webb, T. J., Di Falco, S., et al. (2009). Developing an integrated conceptual framework to understand biodiversity conflicts. Land Use Policy 26, 242-253. doi: 10.1016/j.landusepol.2008.03.005

Zeller, K. (2007). Jaguars in the New Millennium Data Set Update: The State of the Jaguar in 2006. New York, NY: Wildlife Conservation Society, 1-82.

Zimmermann, A., Walpole, M. J., and Leaderwilliams, N. (2005). Cattle ranchers' attitudes to conflicts with jaguar (Panthera onca) in the Pantanal of Brazil. Fauna and Flora International. Oryx 39, 406-412. doi: $10.1017 /$ S0030605305000992

Conflict of Interest: The authors declare that the research was conducted in the absence of any commercial or financial relationships that could be construed as a potential conflict of interest.

Copyright (๐ 2019 Knox, Negrões, Marchini, Barboza, Guanacoma, Balhau, Tobler and Glikman. This is an open-access article distributed under the terms of the Creative Commons Attribution License (CC BY). The use, distribution or reproduction in other forums is permitted, provided the original author(s) and the copyright owner(s) are credited and that the original publication in this journal is cited, in accordance with accepted academic practice. No use, distribution or reproduction is permitted which does not comply with these terms. 